\title{
THE PROBLEM OF DUST STORMS: PROTECTION METHODS AND MACRO-STRUCTURES IN LANDSCAPE ARCHITECTURE
}

\author{
A.E. Abdegalieva, E.Y. Zaykova \\ RUDN University \\ Miklukho-Maklay str., 8/9, Moscow, Russia, 117198
}

\begin{abstract}
For people living in arid areas with an arid climate and constant dust-storms, there is a need to hide from the wind flow arises very often. Dust storms occur continuously on our planet, and the use of its power and the wind force developssustainably in the modern world. Sustainable development - is a model of natural resources use, the model of interaction between a human and nature, a model of civilization progress on the basis of innovation, which is achieved by quenching the vital needs of the modern generation along with environment saving, strengthening personal and public health, without losing this opportunity for future generations. Studied foreign experience allows to propose new methods of dealing with dust storms, as well as the new form of protective structures in urban space with the use of modern means of landscape design.
\end{abstract}

Key words: ecological disaster, dust storm, Kyzylorda environment, protection methods from dust storms, protection constructions from dust storms, the plants of the local flora, local rock formation, environmental design, environment sustainability within macro-structures in landscape

\section{INTRODUCTION}

Recently, dust (sand) storms, in their scale, can be attributed to global natural disasters, which can cause serious environmental problems later, storms are insufficiently studied, in connection with various atmospheric parameters that determine their occurrence and development.

Dust (sand) storm - is the rise caused by strong winds from the earth's surface and the air streams transfer of dust, sand, salt and other particle of less than one millimeter in size [1]. In the recent years the identification of source areas for dust storms has been an important area or research, with the Sahara (especially Bodélé) and western China being recognized as the strongest sources globally [9]. This phenomenon is widely spread in desert, semi-desert and steppe regions of the planet. One of such areas include the southern part of Republic of Kazakhstan, Kyzylorda city, where dust storms occur frequently. During strong storms in Kazakhstan, wind speeds can exceed 25-30 m/s. Storms belong to local micrometeorological phenomena, i.e. have a linear manifestation scale in amount of tens or hundreds kilometers. Areas, that capture dust storm are very diverse - from minor areas of several hundred square meters, up to colossal, hundreds or thousands and even millions of square kilometers. According to duration, this phenomenon can be short - a few minutes, as well as long — several days. A storm cause is considered to be a turbulent whirlwinds that arise in wind strengthening, and strong vertical currents are formed by heating of the Earth's surface. One of the reasons of dust storm occurrence is a strong soil dryness dustiness. The occurrence of its intensity also depend on the number and nature of precipitation [2]. Strong destruction and blow- 
ing of soil, as well as the transfer of sand, salt and other particles by air flows, provides great harm to a human health, first of all, and to is economic activity. In an urban environment, high dust content can be a consequence of serious ecological and genetic problems. On the basis of existing data for 2006 of Kyzylordaregion, the dust concentration in the air is $1.7 \mathrm{mg} / \mathrm{m}(\mathrm{MPC}-0.15 \mathrm{mg} / \mathrm{m})$, and presence of harmful substances in the air: nitrogen dioxide (MPC $-0.2 \mathrm{mg} / \mathrm{m})-1.9 \mathrm{mg} / \mathrm{m}$, ammonia (MPC $-0.2 \mathrm{mg} / \mathrm{m})$ $1.0 \mathrm{mg} / \mathrm{m}$.

$44.5 \%$ of the region diseases are the respiratory system diseases [3]. The environmental disasterterritory like Aral sea, as well as existing cosmodrome "Baikonur" are the parts of Kyzylorda region, that served as the negative influence of dispersion of dust, harmful particles and salts in the air. In relation to the existing environmental situation in Kyzylorda region and, in particular, in Kyzylorda city, at the present stage, the research of new forms in landscape architecture, contributing to the solution of this problem of heavy storms is essential. Therefore this paper aims to review methods considering the solution analysis of the problem.

Aims and goals. The aim of this study is to examine the nature of the dust storms, direction of the wind velocity and dust flow scheme. The aim of the study is also the research of new model of the macro-structure in the landscape, integrating in its structure both artificial and natural materials. the objective of the research is to find a landscape model of the space in which the shape and design of the macro-structure as a protective element. Macro-structure will help to reduce the flow velocity of the dust, silt detention, and in the absence of dust storms will form the basis of the composition for the organization of recreational space squares, boulevards and squares.

\section{MATERIAL AND METHODS}

The whole territory of Kyzylorda region is characterized by frequent and strong winds, especially in north-east direction. Their average annual speed is ranged from 3.1 to $6.0 \mathrm{~m} / \mathrm{s}$. The most dangerous storms are the storms, the speed of which exceeds 15 $20 \mathrm{~m} / \mathrm{s}$. During strong storms in Kazakhstan, wind speeds can exceed $25-30 \mathrm{~m} / \mathrm{s}$. To prevent and reduce the dust storms effects, there is a use of several methods: the design of urban facilities (public and residential buildings), creations of forest shelter belts and hedges as well as artificial designs. This paper review the individual methods and evaluates the efficiency of those In the process of urbanization the natural environment changes., An artificial environment for humans is created due to efficient organization of urban systems, sustainable agricultural, forestry and industrial use of land and water resources. The knowledge of the laws of equilibrium between the primary and the urban environment will allow regulating urban planning processes properly, to produce optimal requirements for the planning and building of settlements, space-planning decisions of housing and community facilities, engineering networks, landscaping, taking into account the specific of an area climatic conditions [4].

In forming cities in areas with dust storms it is necessary to search for a compact, serried urban structures (reduction of the vehicle and pedestrian communication length, architectural compositionsisolation, etc.) that react to wind effects as a whole [5]. On the 
periphery of the settlements in the dust and wind flow path it is recommended to build rows of terraced houses with gardens. Two-storey construction will reduce the dust rate from $20-30 \%$ up to $80 \%$ [6]. Thus, the effective protection of the urban environment from dust storms will be achieved by comprehensive application of architectural, constructive and engineering tools according to specific local conditions.

Protective forest plantations - arethe artificially created forest plantations for protection from adverse natural and anthropogenic factors, including drought, water and wind erosion. These plantations can be in the form of forestlands, shelterbelts and clumps, designed to protect the natural, agricultural, industrial, municipal, transportation and other facilities. The protective effect of shelterbelts is expressed both in the immediate protection of soil and crops from dust storms, as well as in the creation of environment conditions to fight against them [7]. Shelterbelts are laid not only in the area, but also in the urban environment exposed to dust storms most of all. Shelterbelts are more effective not only for dust transportation detention, but for the riding air flows dedusting, what is the result of turbulent mixing in treecrowns. Dust-wind strips are placed on the edge of city building and mutually linked with the system of urban landscaping and complex of special ameliorative measures (soil improvement, organization of irrigation and drainage, plant protection from hot winds, etc.). In residential complexes, green spaces, strips are placed with a width of $10-12 \mathrm{~m}$. along the buildings facades, playgrounds and sports complexes, and so on.To create forest plantations it is necessary to use resistant to the local (Kyzylorda region) climatic conditions tree species such as ash, poplar, elm, white willow and maple.

Hedge is another one frequently used element of modern landscape architecture. A hedge is designed to perform not only an aesthetic function, but it is also able to protect area securely from adverse climatic conditions, in particular, as a dust storm and strong wind.At the same time, it's a beautiful landscape design that could provide the urban environment with the natural appearance and attractiveness.Among the existing varieties of hedges, there is a living wall to deal with a storm. The height of living wall can reach 2.5 meters and above. The advantage of living wall is that it stops the massive wind flow, but remains breathable, it does not inhibit natural ventilation, what has a beneficial effect on all the surrounding landing (cannot impact positively on all landings). It is especially important during periods of heat and high humidity. Such fences in Kyzylorda region can be obtained by the use shrubs that are resistant to the local climate characteristics, such as: cingil, oleaster, rose, Russian olive, sea buckthorn.

The most feasible and reliable options can be constructions that consist of both natural and artificial materials. High constructions, as fences, special hedges, small architectural forms, can stop stronger wind. Such windproof models can be made of different materials like wood, polycarbonate, plexiglass, stone and other. This method can be developed and proposed by landscape architects, both in terms of design element in the city, as well as the solution of environmental problems. Such design solutions may be used as a visual sign in the urban environment. Visual signs of a landscape object can be objective and subjective, depending on a garden supervisor, the breadth of his vision and creativity in general [8]. 
By studying this method, we have identified several methods that will be used in our work to help create the most efficient design for protection against dust storms.

1. Metod of regenerate the nature - the creation of a sustainable development of the environment in the urban structure. The main purpose of this method is the formation of corners in the nature of a city by use of natural materials. That is, the proposed structure will not only create an "ecological shield", thereby stopping the flow of the wind during dust storms, as well as during a lull, will perform aesthetic functions in the city, using a natural component. The green component will strengthen the "ecological shield" by planting local flora, thus creating even a small shadow that is a significant factor in hot, dry climates. The term "natural materials" refers to the use of local stone (mineral) femolita. This breed has excellent construction performance, wide range of colors from white to various shades of gray, which can be used to create identical structures in different parts of the city and outside it in different areas. Natural regenerate method will create an ecological balance in the city.

2. Metod "trap" is based on the location of the proposed model depending on the direction and speed of wind storms. The main objective, which serves as a method of position macro-model, taking into account the arrangement according to the different angular degrees in the plane or in the opposite position to the wind direction. Also, this method supports the residents of the city at different time intervals: how macro-structure with shelter and safety functions, then as a resting place in the shade with natural ingredients in its structure, how identical the composition of the urban landscape.

3. Metod semantics scale - method considers the signs and semantic images in terms of their notional value. Its main idea is to design a tablet — picture the earth's surface, and the shape of the semantic macro-structure. For a stronger development of different aspects of the theme of the sign may be involved, associated with the area, such as - the city's history, national characteristics, national symbols, and others. Supposed as semantic sign will be ambitious and will form a single composition in space, characterized by a ratio of parts, size structures commensurate with the environment and for human comfort. The scale not only indicates the actual size of the audience macrostructure, but also gives it a semantic image required for this particular urban space. According to our model is the macro-structure of this article title, then there will be large-scale dimensions. The maximum size of the macro-structure is in the process of refinement, and a final alignment of the scheme will also be in terms of research.

In terms of implementation of such structures and in order to maximize economy, it is recommended to use materials of local origin, such as local stone (mineral) as femolit. This breed has excellent construction performance, wide range of colors from white to various shades of gray that can be used to create identical structures in different parts of a city, outside of it and in different areas.

As an example, the «Furnished shelter forth homeless at Sundholm» project in Copenhagen, which means "Furniture as a shelter for homeless people". The project is based on the constructions in landscape style, crafted from 94 plywood elements. These structures are different in heights, made of polycarbonate material with thickness of $4 \mathrm{~mm}$, fastened together by bolts. This construction solved the problem for homeless people, helping them to hide from bad weather, because the construction is water-resistant, 
windproof and sound proof. This construction solved social, aesthetic and environmental problem. Environmental problem means not only protection from dust storms and moisture protection, but the planting of green component in the urban environment as well.

\section{RESEARCH RESULTS}

Dust storms over the last $50-60$ years, due to several reasons have ceased to be studied intensively, so to accomplish the result of the study we have used historical data of the dust storms. We compared the at different times and the following results. The figures for the 20-year period allowed to establish non-uniformity of distribution of dust storms, both in time and in space. The figures for the 20-year period allowed to establish non-uniformity of dust storms distribution within both time and space. In the area of Kyzylorda region dust storms can occur in all months of the year. But, however, significant indicators (about 85\%) are in warm season, from April to September.

The graph 1.2 [2] shows the repeatability of dust storms by month and its value as a percentage. As shown in Figure 1 in Kyzylorda oblast maximum wind shifted to May, as well as for the IV-IX period, the figure was 446.

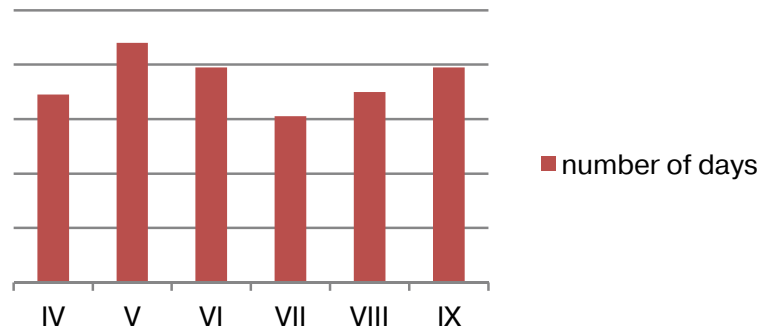

Figure 1. Repeatability (number of days) dust storms

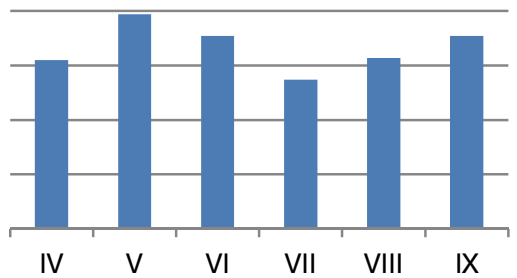

value

of the number

Figure 2. The average value of the number of days with dust storm

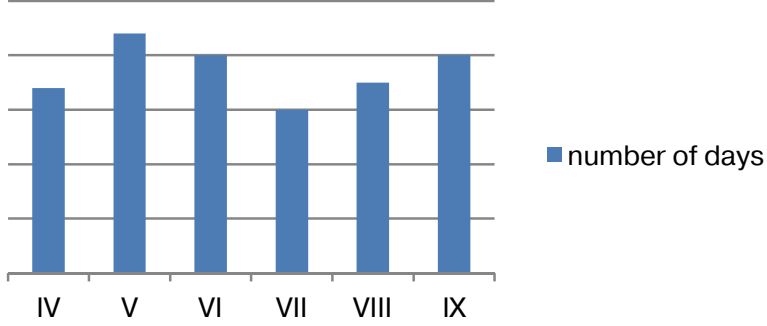

Figure 3. The maximum number of days with dust storm on months of the warm period 


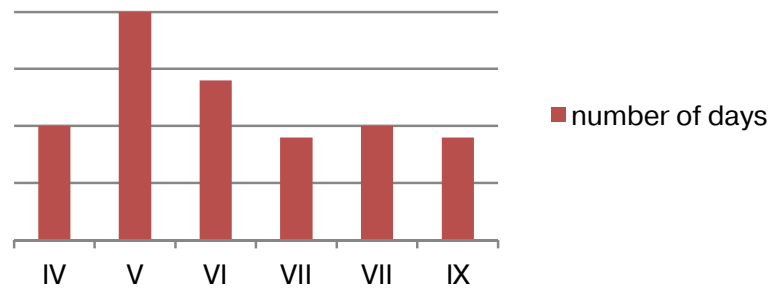

Figure 4. The maximum number of days with dust storm on months of the warm period

Cities of southern Kazakhstan, such as the Shymkent and Kyzylorda, are the heightened areas of dust storms occurrence, since they are in a desert area, within the boundaries of the sand massifs, Alakum and the right bank of Syrdarya river and the Eastern part of the Kyzylkumsands, little planted by vegetation, with patches of sand dunes. On the territory of Kyzylorda region the average number of days with dust storm is equal to 22.3. According to the schedule 3.4 [2] it can be seen that the average and maximum number of days with dust storm falls, as the month of May.

Strong dust storms in Kyzylorda region occur mainly in the Eastern and NorthEastern winds. In table 1, there is the data of wind speed in $\mathrm{m} / \mathrm{s}$, with dust storms $>$ 12 hours and frequency of occurrence (\%) speed $>15 \mathrm{~m} / \mathrm{s}$ by month. All figures, shown in tables and graphs, will be taken into account in deciding the form of the proposed construction in urban environment, as well as the direction and scope of this construction. Historical characteristics of the city, its peculiarities, and the climatic conditions for plants use, that are resistant to these factors, are important.

Table 1

Wind speed in $\mathrm{m} / \mathrm{s}$, with dust storms $>12$ hours and frequency of occurrence (\%) speed $>15 \mathrm{~m} / \mathrm{s}$ by month

\begin{tabular}{|c|c|c|c|c|c|c|c|}
\hline Station & IV & V & VI & VII & VIII & IX & For IV-IX \\
\hline Kyzylorda & $12-28 / 88$ & $17-20 / 100$ & $20 / 100$ & - & - & $10-17 / 80$ & $12-28 / 88$ \\
\hline
\end{tabular}

Graph 5 [2] shows the performance of the highest duration of dust storms by month, which in Kyzylorda region is in August, the month of September.

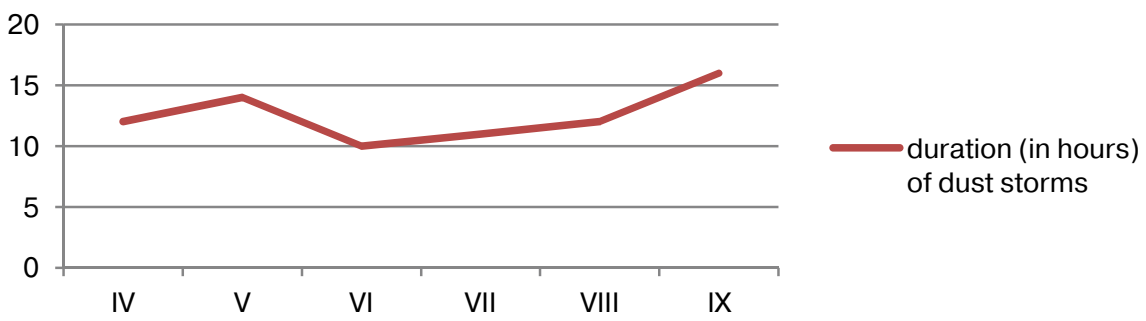

Figure 5. Maximum duration (in hours) of dust storms 
Being at the stage of modeling the process of dust storms, including analysis of digital data by frequency and intensity of this process, we offer a use of macro-structure in the form of geo plastic forms of different sizes, that disrupts a power of wind flow and delay the dust particles on its surface, as a basic shield for this phenomenon. So, as a form of this construction, bionic form, resembling a rice grain is proposed. So, as a form of this construction, bionic form of tablet design, resembling a rice grain is proposed (Figure 6). Such grain figure is due to the fact that Kyzylorda region is on the first place for rice cultivation and its export to other cities. To make this model not monotonous, it is proposed to cut and make it different-leveled for planting shrubs and native flora serving natural shield to trap dust particles and for aesthetic reasons (Figure 7). For the construction, natural stone will be used, mined in the region and in the area of urban-type settlement of Zhanakorgan (Figure 8).

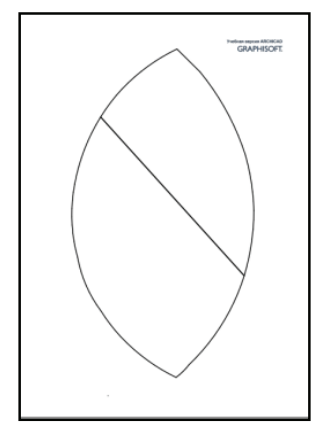

Figure 6. Tablet design

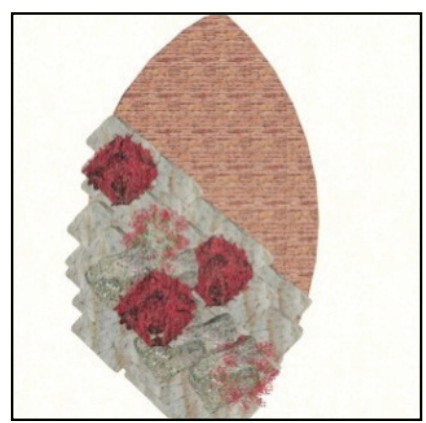

Figure 7. View from above

As the local flora is expected planting low shrubs that will create a more favorable and the natural environment in an urban environment (Figure 9).

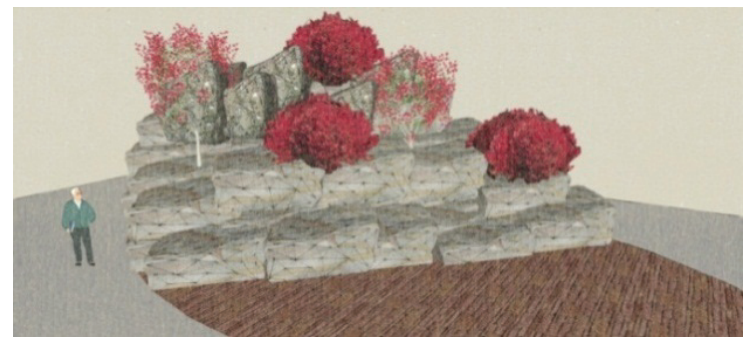

Figure 8. Macro view of construction

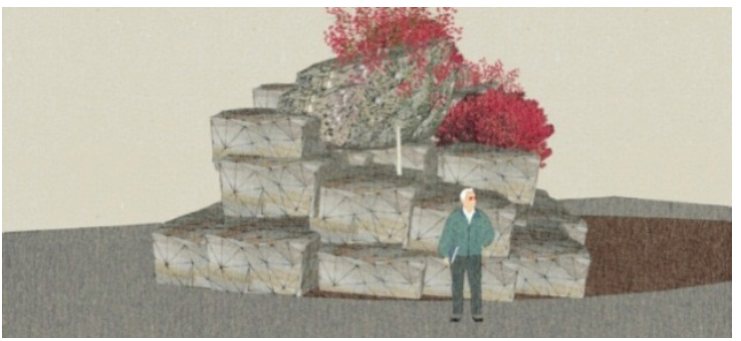

Figure 9. Commensurate scale 


\section{CONCLUSIONS AND RECOMMENDATIONS}

Attempts to solve the environmental problem at different stages of its occurrence in several scientific studies, for example in the article "Macro-constriction in the urban landscape as a way of protection from sandy winds" in the proceedings of the international conference "Public space and urban landscape architecture. The search for new solutions". However it raises only questions of the problem of dust storms and there is a solution, and in this study we have found methods of ecological disaster adapt to the new landscape technology of XX-th century. They are based on the principles of sustainable landscape development for Kyzyordinskoy area. In view of the above methods, it is possible to make the first conclusions that shown and described construction will solve the environmental problems of the city of Kyzylorda, which scale is capable of stopping the flow of strong wind. Such a model of protection from dust storms related to sustainable development and will allow city residents to be Kyzylrda be in natural surroundings, but in the city structure. The position of elements of different size construction will depend on the wind direction and speed, which will be located in open spaces in the urban environment, which refers to the method "traps". Knowing the wind direction (north and northeast), we can assume that most locally and they will be located in the northeastern part of the city (Figure 10).

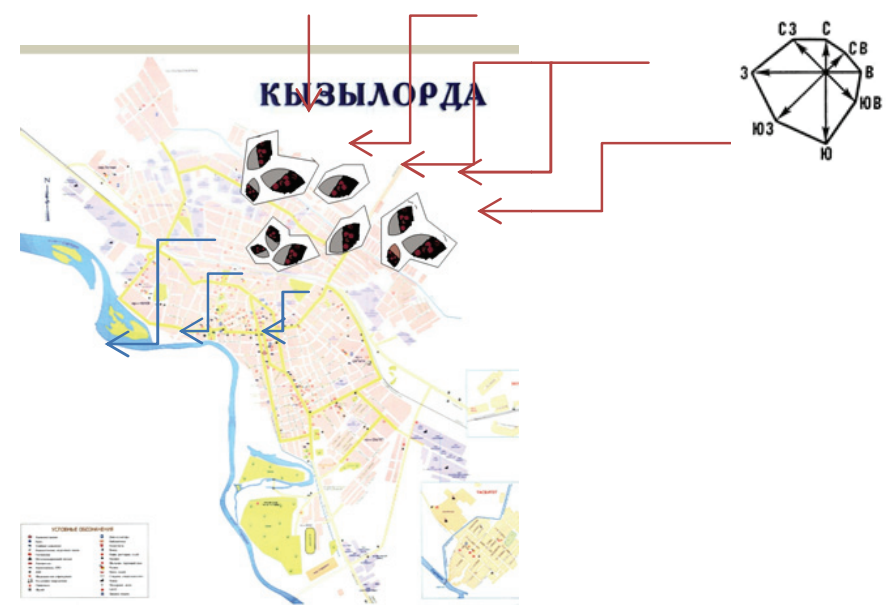

Figure 10. The position of the elements of design [the Map taken from the official site of akimat of Kyzylorda city]

In Figure 10, we can observe how the construction data in this part of town and become an obstacle to defuse the wind moving north-east direction. In daily use, they are a new form of city park with macro-structures, which are arranged in a circuit different functional areas for recreation, sport, walking.

(C) A.E. Abdegalieva, E. Y. Zaykova, 2016 


\title{
REFERENCES
}

[1] Semenov O.E. (2011) Introduction to experimental meteorology and climatology of the sand storms. Almaty, 580 p. (in Russian).

[2] Agarkova A.P. Dust storms and their prognosis. M.: Gidrometeoizdat, 1981 (in Russian).

[3] Ermuhanova N.B. Influence of natural and anthropogenic factors on the health of the population in the zone of ecological disaster: Dis. ... Phd. KSU KorkytAta. Kyzylorda, 2015. 5 (in Russian).

[4] Bektemisov A.S. Construction problems in the complex hydrogeological conditions in areas of dust storms in Kazakhstan // Collection of papers of Republican conference on the problems of design and construction in IV climatic area with dust storms and adverse engineeringgeological conditions in cities and settlements of the Kazakh SSR. 1978. S. 1-5 (in Russian).

[5] Merkert I.A., Karch L.A., Roganova Z.N. Urban planning and typological features of design of residential and public buildings in areas with dust storm // a Collection of papers of Republican conference on the problems of design and construction in IV climatic area with dust storms and adverse engineering-geological conditions in cities and settlements of the Kazakh SSR. 1978. P. 7-10 (in Russian).

[6] Lakcevic, V.K., Darbinian, S.D. Issues of methodology for assessing the dustiness of the home and control // Collection of papers of Republican conference on problems of design and construction in the IVth climatic area with dust storms and adverse engineering-geological conditions in cities and settlements of the Kazakh SSR. 1978. S. 13-16 (in Russian).

[7] Zakharov P.S. Dust storms and fight with them. Rostov-on-don, 1961 (in Russian).

[8] Zaykova E.Y. Typological basis for the design of the iconic landscape environment // RUDN Journal of Agronomy and Animal Industries, No. 2, 2015, pp. 53-56 (in Russian).

[9] Andrew S. Dust storms: Recent developments // Journal of Environmental Management, Volume 90, Issue 1, January 2009, pp. 89-94.

DOI: $10.22363 / 2312-797 X-2016-4-85-93$

\section{ПРОБЛЕМА ПЫЛЕВЫХ БУРЬ: МЕТОДЫ ЗАЩИТЫ И МАКРОКОНСТРУКЦИИ В ЛАНДШАФТНОЙ АРХИТЕКТУРЕ}

\author{
А.Е. Абдегалиева, Е.Ю. Зайкова \\ Российский университет дружбы народов \\ ул. Миклухо-Маклая, 8/2, Москва, Россия, 117198
}

\begin{abstract}
У людей, живущих в аридных районах, с засушливым климатом и пыльными бурями, очень часто возникает необходимость укрыться от потоков ветра. Пыльные бури происходят на нашей планете постоянно, и использование их мощности и силы ветра в современном мире приводит к неистощаемому, то есть устойчивому развитию. Устойчивое, неистощаемое развитие - это модель потребления природных ресурсов, при которой достигается удовлетворение жизненных потребностей современного поколения совместно с сохранением окружающей среды, упрочнением личностного и общественного здоровья без потери такой возможности для будущих поколений. Изученный зарубежный опыт позволяет предложить новые методы борьбы с пыльными бурями, а так же новую форму защитных конструкций в городском пространстве с использованием современных средств ландшафтного дизайна.
\end{abstract}

Ключевые слова: экологическая катастрофа, пыльные бури, экология Кызылорды, методы защиты от пыльных бурь, конструкции для защиты от пыльных бурь, растения местной флоры, местная каменная порода, экологический дизайн, устойчивость среды через макроконструкции в ландшафте 